\title{
Transit-oriented development and the frequency of modal use
}

\author{
Robert B. Noland \\ Rutgers University \\ rnoland@rutgers.edu
}

\author{
Stephanie DiPetrillo \\ Rutgers University \\ sed@rutgers.edu
}

\begin{abstract}
Transit-oriented development (TOD) is assumed to be effective at changing the travel behavior of individuals, particularly in increasing the use of public transit, but also by increasing walking activity while decreasing driving. The analysis presented here examines the frequency of using these modes of travel for those living in TODs and proximate to a train station versus those living more distantly. Household survey data was collected for the area surrounding eight rail stations in the state of New Jersey in the United States. The models developed include factors that control for attitudes about the neighborhood where respondents reside and how long they have lived at their current residence. Other control variables to represent the urban design of the neighborhood are also included. A factor analysis of the attitudinal variables produces five factors that are used as controls in an ordered structural equation model of frequency of using public transit, walking, and driving. Results suggest that those living in TODs and closer to the train station use public transit and walk more frequently than those living farther out; they also drive less frequently than those living farther out.
\end{abstract}

\author{
Article history: \\ Received: November 19, \\ 2013 \\ Received in revised form: \\ April 25, 2014 \\ Accepted: April 25, 2014 \\ Available online: April 8, \\ 2015
}

\section{$1 \quad$ Introduction}

Many municipalities with train stations in New Jersey are seeking to focus new development near their train stations. Over the last 15 years or so, transit-oriented developments (TODs) have been built near many stations in the state. These are often combined with walkability improvements in the area around the station and efforts to promote development in the town center (which is often adjacent to the train station). The new residents of these TODs may be more likely to use the train for their commute trips as many stations have direct service to Manhattan. Travel behavior of the TOD residents and those who live relatively close to the station may differ from those living farther afield. The objective of this study was to examine these effects, specifically how the frequency of using different modes of travel is associated with residence location while controlling for many of the other features of a TOD area.

Household survey data was collected within 2 miles of eight rail stations (seven commuter rail and one light-rail) in New Jersey. The data collection included detailed data on respondents' attitudes toward living in their current location. This is one way to potentially control for self-selection bias, which has plagued many studies that seek to correlate locational variables with travel behavior. We also controlled for how long residents had lived in their current location. To analyze these data a structural equation model (SEM) was specified using the frequency of traveling by car, walking, and public transit as simultaneous dependent variables. We are not familiar with other research in travel behavior that has taken

Copyright 2015 Robert B. Noland and Stephanie DiPetrillo

http://dx.doi.org/10.5198/jtlu.2015.517

ISSN: 1938-7849 | Licensed under the Creative Commons Attribution - Noncommercial License 3.0

The Journal of Transport and Land Use is the official journal of the World Society for Transport and Land Use (WSTLUR) and is published and sponsored by the University of Minnesota Center for Transportation Studies. This paper is also published with sponsorship from WSTLUR and the Institutes of Transportation Studies at the University of California, Davis, and the University of California, Berkeley. 
this approach. SEM models allow for the simultaneous control of various interactions between variables and are considered to show causal effects.

We begin with a brief literature review that focuses on studies that have analyzed TODs and travel behavior. While we recognize the large literature on associations between travel behavior and urban design, density, and diversity, we mainly cover the relevant literature on TODs. Our data collection process and strategy is then presented followed by our data analysis, beginning with our theoretical framework and a discussion of our attitudinal variables, followed by the SEM analysis.

\section{$2 \quad$ Literature review}

The literature reports considerable evidence that TOD residents drive less than those living in nontransit-supportive locations (Ewing and Cervero 2010, Arrington et al. 2008). The density, mix of uses, and relative accessibility allows residents as well as workers and visitors to fulfill at least some of their daily needs without driving.

Cervero (2004) found evidence that many TOD ridership gains were a result of self-selectionindividuals who choose a residential location in order to be close to transit. Analyzing travel diaries from California residents, it was found that nearly 20 percent of those who lived within 0.5 miles of transit used transit to travel to work, compared to less than 9 percent of those living more than 0.5 miles from a station (Cervero 2004).

A key question is whether those who desire to drive less choose to live in transit-accessible locations. If this is the case, then this self-selection into certain neighborhoods could potentially bias statistical results. However, recent research that has sought to control for self-selection bias has found that it plays a small role and that statistical associations are still substantial (Cao et al. 2009b). Thus, despite any self-selection bias, TODs can still lead to net reductions in vehicle travel. Chatman (2009) suggests that those households that value accessibility most may be most set in their ways; that is, they take transit already, while those who value accessibility least are more likely to change their behavior if they live in a TOD. Thus, self-selection could lead to underestimates of the impact of TODs on travel (Chatman 2009).

One potential impact on travel behavior is the effect of TODs on vehicle miles traveled (VMT). Reductions in VMT result in lower energy demands as well as reduced demands on the road network. Lower energy demands have economic and environmental benefits while reduced demands on the road network can result in lower long-term investment requirements (Cambridge Systematics Inc. 2006).

Cervero and Arrington (2008) found that residents of 17 TODs averaged 44 percent fewer vehicle trips than estimates based on the trip generation manual published by the Institute of Transportation Engineers. The authors noted that vehicle trip rates were particularly low in Washington, DC, and Portland, Oregon, where regional and corridor planning for TOD has been adopted, and that neighborhood densities and vehicle trip rates were inversely proportional. That is, as densities rise, trip rates fell. These findings suggest that attempts to model the effects of TODs must account for regional planning practices and neighborhood land-use characteristics (Arrington et al. 2008, Cervero and Arrington 2008). Looking only at commute trips, Arrington et al. (2008) found that residents living near transit were five to six times more likely to commute by transit than others living in the region (Arrington et al. 2008).

While residential density is a key feature of TODs, the mix of land uses within TODs can also reduce vehicle travel. Bartholomew and Ewing (2010) noted that increases in proximity and convenience allowed TOD residents, workers, and visitors to complete their daily activities within a smaller area, which results in shorter travel distances, lower average vehicle trip rates, and lower VMT (Bartholomew and Ewing 2010, Bartholomew and Ewing 2011). A recent review disentangled the effects of the " 5 Ds" associated with smart growth-density, diversity, design, destination accessibility, and distance to transitnoting that diversity tends to lead to more walking than most other effects, with the exception of design features (Ewing and Cervero 2010). 
Recent work (Boarnet et al. 2010) attempts to parse out whether VMT reduction is simply due to the presence of transit (rail and bus) or whether land use plays a significant role. Looking at detailed travel diary data from the greater Los Angeles area, these researchers examined land-use characteristics at the neighborhood level as well as regional access to jobs and to the transportation network. They found that there was large variation in how proximity to transit affected travel. One consequence is that studying regional average features of the built environment may mask many of the more localized impacts that affect individual travel decisions (Boarnet et al. 2010).

Looking at barriers to TODs in New Jersey, Chatman and DiPetrillo (2010) found that auto commuting and auto ownership were strongly correlated with housing type (size) and tenure as well as the amount of available parking, and less so by rail station access. These findings suggest that an effective TOD impact model should include measures of housing characteristics and parking availability (as well as parking regulation and policies) in addition to mere numbers of units (Chatman and DiPetrillo 2010).

Our analysis builds on this prior literature. Original data was collected near eight train stations in New Jersey. The analysis that follows focuses on how residents who live either closer to the station or farther afield travel, using a variety of self-reported measures. The next section discusses our data collection strategy and this is followed by the analysis and results.

\section{Data collection}

Data was collected in summer 2012 using a combined online/printed survey of households residing in or near eight locations with rail transit. The sampling frame targeted 1000 randomly selected households in each site-stratified by distance from the station. These strata were for households located within 0.5 miles of the station ( 400 respondents or 40 percent of the sample), those residing in new or substantially renovated structures within 0.25 miles of the station (up to 200 respondents or 20 percent of the sample), and those living between 0.5 and 2.0 miles from the station. For Metuchen, Cranford, and Plainfield stations, there were fewer than 200 addresses for new housing. Metuchen had no new housing, Cranford had 66 residences, and Plainfield had 75. The balance of the sample for these locations was reallocated to the 0.5 -mile radius strata in each case.

The stations were selected in consultation with staff from NJ Transit and represent a broad range of different demographic characteristics. Metuchen and Cranford are relatively affluent areas, while Plainfield, New Brunswick, and Newark are relatively low income (see Table 1). Different transit lines were also selected. Most are commuter rail lines, but Newark Broad St. is served both by commuter rail and the Newark subway (a light rail line), and Essex St. in Jersey City is served by the Hudson-Bergen Light Rail line. Figure 1 displays the geographic location of the stations. 
Table 1: Demographics by municipality

\begin{tabular}{|c|c|c|c|c|c|c|c|c|c|}
\hline Municipality & County & Station & Line & $\begin{array}{l}\text { Station } \\
\text { ridership } \\
(\mathrm{FY} 11) \\
\end{array}$ & $\begin{array}{l}\text { Ridership } \\
\text { on line }\end{array}$ & $\begin{array}{l}\% \text { of } \\
\text { line }\end{array}$ & $\begin{array}{l}\text { Total } \\
\text { popula- } \\
\text { tion }\end{array}$ & $\begin{array}{c}\text { Population } \\
\text { density } \\
\text { (pop/sq mi) }\end{array}$ & $\begin{array}{c}\text { Median } \\
\mathrm{HH} \\
\text { income }\end{array}$ \\
\hline Newark & Essex & Broad St & $\begin{array}{l}\text { Morris \& Es- } \\
\text { sex / Newark } \\
\text { Light Rail }\end{array}$ & 2316 & 52,300 & $4.4 \%$ & 274,674 & 11,356 & $\$ 35,659$ \\
\hline Jersey City & Hudson & Essex St & $\begin{array}{l}\text { Hudson- } \\
\text { Bergen Light } \\
\text { Rail }\end{array}$ & 1152 & 41,000 & $2.8 \%$ & 243,257 & 16,447 & $\$ 54,280$ \\
\hline Metuchen & Middlesex & Metuchen & $\begin{array}{l}\text { Northeast } \\
\text { Corridor }\end{array}$ & 3795 & 110,800 & $3.4 \%$ & 13,431 & 4859 & $\$ 94,410$ \\
\hline $\begin{array}{l}\text { New Bruns- } \\
\text { wick }\end{array}$ & Middlesex & $\begin{array}{l}\text { New } \\
\text { Brunswick }\end{array}$ & $\begin{array}{l}\text { Northeast } \\
\text { Corridor }\end{array}$ & 4879 & 110,800 & $4.4 \%$ & 53,933 & 10,312 & $\$ 44,543$ \\
\hline Morristown & Morris & $\begin{array}{l}\text { Morris- } \\
\text { town }\end{array}$ & $\begin{array}{l}\text { Morris \& Es- } \\
\text { sex }\end{array}$ & 1846 & 52,300 & $3.5 \%$ & 18,457 & 6299 & $\$ 64,279$ \\
\hline Cranford & Union & Cranford & Raritan Valley & 1189 & 21,250 & $5.6 \%$ & 22,414 & 4641 & $\$ 107,052$ \\
\hline Plainfield & Union & Plainfield & Raritan Valley & 897 & 21,250 & $4.2 \%$ & 49,043 & 8147 & $\$ 52,056$ \\
\hline Rahway & Union & Rahway & $\begin{array}{l}\text { Northeast } \\
\text { Corridor / } \\
\text { North Jersey } \\
\text { Coast Line }\end{array}$ & 3066 & 110,800 & $2.8 \%$ & 26,968 & 6915 & $\$ 58,551$ \\
\hline
\end{tabular}




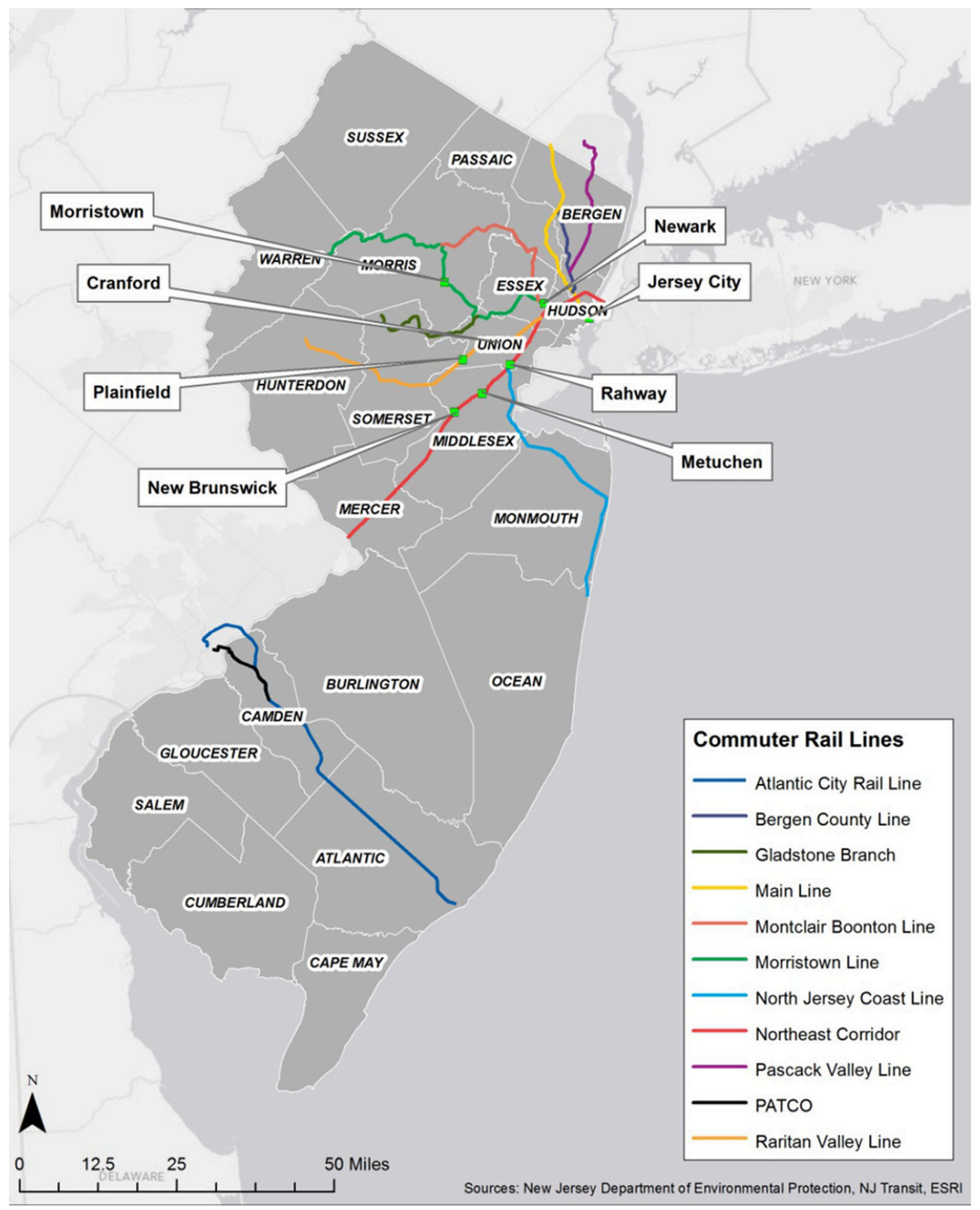

Figure 1: Map of station locations and NJ TRANSIT rail lines Source: NJ TRANSIT

Our survey protocol included an advance letter advising respondents that they will receive the survey, a survey invitation directing respondents to the online questionnaire, a three-day follow-up postcard, a three-week follow-up letter, and a final follow-up letter with a printed questionnaire (Dillman 2000). All households received a $\$ 1$ bill as incentive to encourage their participation. In an effort to increase response rates from underperforming station areas (specifically Newark Broad St. and Plainfield), a portion of these households received an additional $\$ 1$ bill incentive in the fifth and final mailing that also delivered the printed questionnaire. Overall, the response rate for the survey was 23.5 percent, though the rate varied by community. The response rate from the poorer and urban communities in Newark and Plainfield were about 15 percent, while the rate from affluent suburban communities such as Metuchen and Cranford were 35.2 percent and 29.3 percent, respectively. A total of 1629 responses were received from 
a mailing of 8000 with 6938 valid addresses. There is no consistent pattern of response rate between the various strata that were sampled. Of those completed surveys received, 74.1 percent completed the questionnaire online; online responses were less in lower-income municipalities. The overall survey response statistics are shown in Table 2.

Table 3 lists the stations as well as information on the response rates, while Table 2 shows the response rate for mail and online versions.

Table 2: Response overview (adjusted ${ }^{a}$ )

\begin{tabular}{lc}
\hline Measure & Statistic \\
\hline Response Rate & $23.5 \%(1629 / 6938)$ \\
Completes & 1629 \\
Completes by Mail & $422(25.9 \%$ of completes $)$ \\
Completes by Web & $1207(74.1 \%$ of completes $)$ \\
Adjusted Sample & 6938 \\
Initial Sample & 8000 \\
Refusals & 118 \\
Vacant Addresses & 192 \\
Bad Addresses & 47 \\
Mail Retuned to Sender & 805 \\
Deceased & 18 \\
'The numbers take into account changes in the sample due to vacant addresses, \\
bad addresses, deceased respondents, and mail returned to sender. \\
bThis number combines the refusals that were received by phone and mail. \\
'This designation refers to mail that was returned marked either "Vacant" or \\
"VAC."
\end{tabular}

Table 3: Response rate by station and strata

\begin{tabular}{lrrrrrrrr}
\hline Station & \multicolumn{2}{c}{ Total Response } & \multicolumn{2}{c}{ New Housing } & \multicolumn{2}{c}{ Inside 0.5 Mile } & \multicolumn{2}{c}{ Outside 0.5 Mile } \\
\hline Broad Street & $15.2 \%$ & $117 / 772$ & $23.2 \%$ & $22 / 95$ & $16.4 \%$ & $56 / 341$ & $11.6 \%$ & $39 / 336$ \\
Cranford & $29.3 \%$ & $270 / 923$ & $18.2 \%$ & $10 / 55$ & $32.1 \%$ & $159 / 495$ & $27.1 \%$ & $101 / 373$ \\
Essex Street & $22.3 \%$ & $189 / 846$ & $18.2 \%$ & $31 / 170$ & $24.7 \%$ & $86 / 348$ & $22.0 \%$ & $72 / 328$ \\
Metuchen & $35.2 \%$ & $326 / 925$ & $\mathrm{~N} / \mathrm{A}$ & $\mathrm{N} / \mathrm{A}$ & $39.6 \%$ & $222 / 561$ & $28.6 \%$ & $104 / 364$ \\
Morristown & $24.5 \%$ & $217 / 887$ & $21.2 \%$ & $36 / 170$ & $21.5 \%$ & $73 / 339$ & $28.6 \%$ & $108 / 378$ \\
New Brunswick & $20.1 \%$ & $171 / 850$ & $28.2 \%$ & $46 / 163$ & $13.7 \%$ & $45 / 328$ & $22.3 \%$ & $80 / 359$ \\
Plainfield & $15.0 \%$ & $128 / 851$ & $20.6 \%$ & $13 / 63$ & $7.5 \%$ & $32 / 429$ & $23.1 \%$ & $83 / 359$ \\
Rahway & $23.9 \%$ & $211 / 884$ & $28.8 \%$ & $45 / 156$ & $21.1 \%$ & $74 / 350$ & $24.3 \%$ & $92 / 378$ \\
Total & $23.5 \%$ & $1629 / 6938$ & $23.3 \%$ & $203 / 872$ & $23.4 \%$ & $747 / 3191$ & $23.6 \%$ & $679 / 1500$ \\
\hline
\end{tabular}




\section{$4 \quad$ Data analysis}

It is hypothesized that those who live closer to a train station are more likely to use public transit, walk for various activities, and use their cars less. These issues are analyzed using survey data collected for the eight TOD study areas. We approach this analysis using a structural equation model. Our main metric for examining travel behavior is self-reported information on how frequently respondents use various modes of travel. We also collected data on the primary mode of travel for their commute trip. These variables are examined in more detail using a structural equation model that controls for the many interactions associated with mode usage, including attitudes residents have about their neighborhood and how long they have lived there. These controls and interactions are meant to minimize self-selection bias; that is, those who want to use public transit or who want to walk more often will locate closer to the train station and more walkable environments.

The key outcome variable of interest is the frequency that each respondent either drives, walks, or uses public transit. These are measured in the survey instrument based on whether the respondent reported using the mode of travel based on six ordered responses ("every workday," "few times a week," "once a week," "once a month," "few times a year," or "never"). The distribution of these choices for the entire sample is shown in Figure 2.

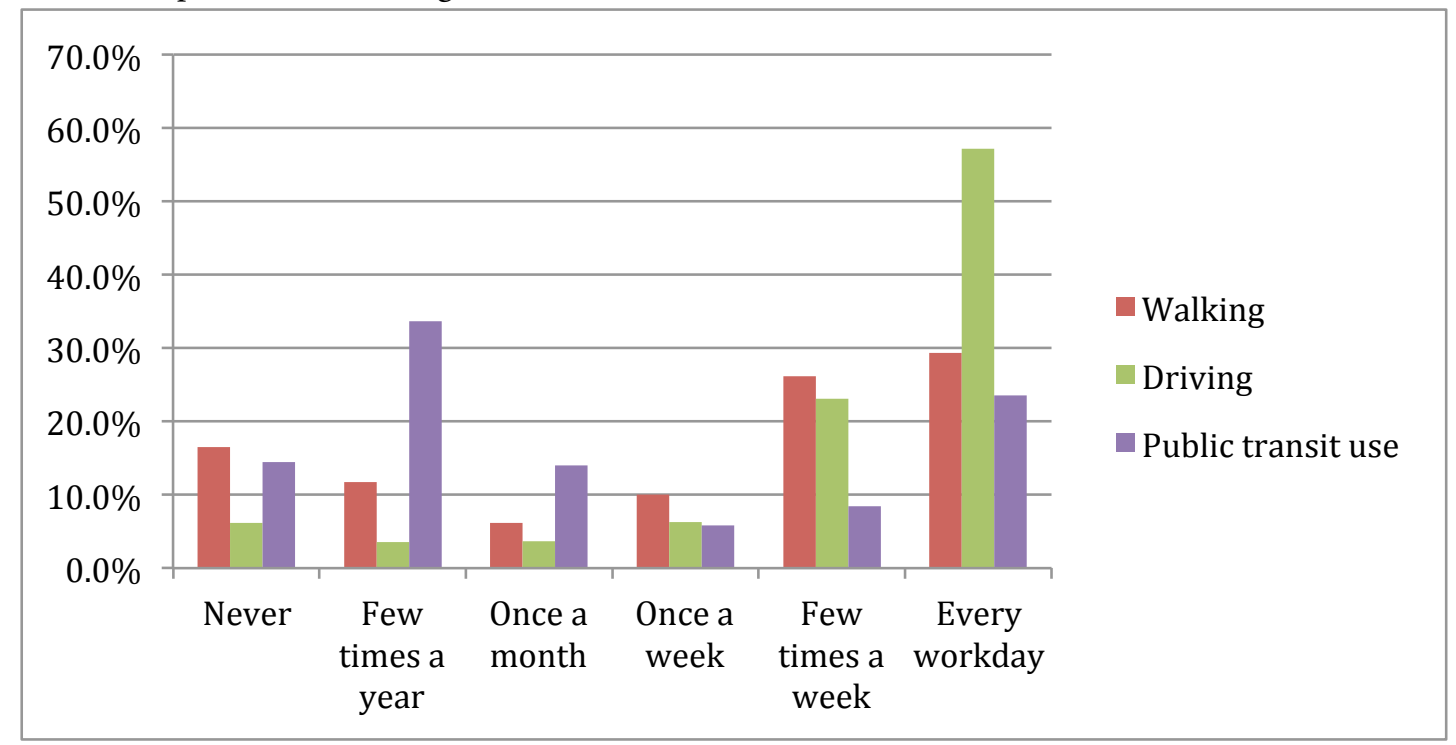

Figure 2: Frequency of mode usage

These relationships are also displayed in tabular format in Table 4 where they are broken down by how close each household is to the train station, by combining those who live in a TOD with those within 0.5 miles of the station compared to those living 0.5 miles to about 2.0 miles from the station. 
Table 4: Cross-tabulations of modal use frequency and distance from train station

\begin{tabular}{|c|c|c|c|c|c|c|c|c|c|}
\hline & \multicolumn{3}{|c|}{ Walking Frequency } & \multicolumn{3}{|c|}{ Public Transit Use Frequency } & \multicolumn{3}{|c|}{ Driving Frequency } \\
\hline Frequency & $\begin{array}{l}\text { Lives in } \\
\text { TOD or } \\
\text { within } \\
0.5 \mathrm{mi}\end{array}$ & $\begin{array}{l}0.5 \text { to } \\
2 \mathrm{mi}\end{array}$ & Total & $\begin{array}{l}\text { Lives in } \\
\text { TOD or } \\
\text { within } 0.5 \\
\text { mi }\end{array}$ & $\begin{array}{l}0.5 \text { to } \\
2 \mathrm{mi}\end{array}$ & Total & $\begin{array}{l}\text { Lives in } \\
\text { TOD or } \\
\text { within } 0.5 \\
\text { mi }\end{array}$ & $\begin{array}{l}0.5 \text { to } \\
2 \mathrm{mi}\end{array}$ & Total \\
\hline $\begin{array}{l}\text { Never to a few } \\
\text { times a year } \\
\text { row } \%\end{array}$ & $\begin{array}{r}174 \\
41.6 \% \\
\end{array}$ & $\begin{array}{r}244 \\
58.4 \% \\
\end{array}$ & 418 & $\begin{array}{r}345 \\
46.7 \% \\
\end{array}$ & $\begin{array}{r}393 \\
53.3 \% \\
\end{array}$ & 738 & $\begin{array}{r}101 \\
67.3 \% \\
\end{array}$ & $\begin{array}{r}49 \\
32.7 \% \\
\end{array}$ & 150 \\
\hline $\begin{array}{l}\text { Once to a few } \\
\text { times a week } \\
\text { row } \%\end{array}$ & $\begin{array}{r}334 \\
62.4 \% \\
\end{array}$ & $\begin{array}{r}201 \\
37.6 \% \\
\end{array}$ & 535 & $\begin{array}{r}155 \\
70.5 \% \\
\end{array}$ & $\begin{array}{r}65 \\
29.5 \% \\
\end{array}$ & 220 & $\begin{array}{r}297 \\
65.4 \% \\
\end{array}$ & $\begin{array}{r}157 \\
34.6 \% \\
\end{array}$ & 454 \\
\hline $\begin{array}{l}\text { Every workday } \\
\text { row } \%\end{array}$ & $\begin{array}{r}313 \\
72.1 \% \\
\end{array}$ & $\begin{array}{r}121 \\
27.9 \% \\
\end{array}$ & 434 & $\begin{array}{r}256 \\
71.1 \% \\
\end{array}$ & $\begin{array}{r}104 \\
28.9 \% \\
\end{array}$ & 360 & $\begin{array}{r}468 \\
53.0 \% \\
\end{array}$ & $\begin{array}{r}415 \\
47.0 \% \\
\end{array}$ & 883 \\
\hline $\begin{array}{l}\text { Total } \\
\text { row } \%\end{array}$ & $\begin{array}{r}866 \\
58.6 \%\end{array}$ & $\begin{array}{r}612 \\
41.4 \% \\
\end{array}$ & 1478 & $\begin{array}{r}901 \\
8.8 \%\end{array}$ & $\begin{array}{r}631 \\
41.2 \% \\
\end{array}$ & 1532 & $\begin{array}{r}900 \\
58.3 \%\end{array}$ & $\begin{array}{r}643 \\
41.7 \% \\
\end{array}$ & 1543 \\
\hline
\end{tabular}

These cross-tabulation results show two primary characteristics of the sample. First, most people drive quite frequently and at least several times a week, if not every workday. However, of those who never drive or only drive a few times a year, proportionally more live within 0.5 miles of the transit station. Second, a sizable fraction of the respondents are infrequent walkers; about 30 percent of the respondents either never walk or do so only a few times a year. More of the infrequent walkers live beyond 0.5 miles from the station. Those who report walking every workday are much more likely to live near the station than farther away. Public transit use is more variable. About half of the respondents either never use public transit or do so only a few times a year. The fraction of those in this category is greater the farther they live from the station. A sizable share of the sample uses public transit every workday and this share is greater for those living close to the station.

These mode use frequency questions were asked in the context of work trips but were not specifically meant to reflect work trips only. This was partly due to how the question was placed within the survey questionnaire, immediately following a section with detailed questions about the work trip.

Additional evidence for the benefits of TOD is revealed in the choice of mode used for work trips. Table 5 provides strong evidence that those living within 0.5 miles of a train station are far more likely to use public transit for their commute trip than those living farther out. They are also less likely to drive to work and, while the absolute values are small, twice as likely to walk to work than those living farther from the station. 
Table 5: Usual mode of work commute in last week by distance from station

\begin{tabular}{l|rrr}
\hline & \multicolumn{2}{|l}{ Distance to Station } & \\
\hline Mode & $\begin{array}{c}\text { Lives in TOD or } \\
\text { within } 0.5 \mathrm{mi}\end{array}$ & 0.5 to $2 \mathrm{mi}$ & Total \\
\hline car or truck & 373 & 310 & 683 \\
row \% & $54.6 \%$ & $45.4 \%$ & 340 \\
\hline public transit & 243 & 97 & 50 \\
row \% & $71.5 \%$ & $28.5 \%$ & 1073 \\
walk & 38 & $24.0 \%$ & \\
row \% & $76.0 \%$ & 419 & \\
\hline Total & 654 & $39.0 \%$ & \\
Row \% & $61.0 \%$ & & \\
\hline
\end{tabular}

\subsection{Theoretical and methodological framework}

One of the key research challenges in evaluating travel choices of those who live in and near TODs is the problem of "self-selection bias." That is, those people who live in or near TODs live there because they prefer to use transit or prefer to walk more, compared to those who are not residents. Most analyses cannot claim to completely control for this; however, one technique that has been used is to control for the attitudes of residents as well as the length of time they have lived in their current location (Cao et al. 2009a).

Our multivariate analysis extends this line of reasoning by including a control for how long residents have lived in their current home. Our hypothesis is that those who have lived in a location for a shorter period of time will be more likely to have selected their neighborhood because of the travel choices available. Therefore, those living at a location for a shorter period of time may be more likely to use transit and to walk, all else equal. This is moderated by how the length of time one has lived in a location is affected by attitudes; that is, the various attitudes each respondent has toward his or her neighborhood and modal choices may also affect how long the person lives in a neighborhood.

The built environment around TOD and station areas is a key metric that can affect travel behavior. Two proxies often used are population density and employment density. Road network variables, such as street and intersection density are also often used in models of travel behavior; intersection data was not available for our analysis. Vehicle ownership has also been found to affect walking behavior. This can also be influenced by the built environment; denser areas tend to result in more difficult driving conditions and more expensive parking, making vehicle ownership less desirable.

Given these intricate relationships, we specify what is known as a path or structural equation model (SEM) (Iacobucci 2009). This allows for simultaneous modeling of the many factors that influence the use of each mode of travel. Our key dependent variable is the reported frequency with which each respondent drives, uses public transit, or walks. (See Figure 3 and Table 4. Figure 3 displays these relationships graphically.

The modal frequencies in Figure 3 are measured by our questions on frequency of using each mode of travel (car, public transit, and walking). These are our key dependent variables and each is crosscorrelated with the other, which is controlled for in our SEM analysis. ${ }^{1}$ These variables are also ordered; that is, they are not continuous variables. Our analysis also controls for this. Ordered variables also prevent us from specifying these as endogenous variables because ordered variables cannot be included as independent variables.

\footnotetext{
${ }^{1}$ We used $\mathrm{R}$ and the lavaan package to estimate the models (Rosseel 2012).
} 
Key control variables include socioeconomic variables (income and average age of household). Other socioeconomic variables were tested, including the presence of children and whether the household owns a dog, but were not found to be important factors. Since the sampling strategy was stratified, we also include categorical variables for each TOD area and for where the respondent lives relative to the station (in a TOD or within 0.5 miles relative to farther out).

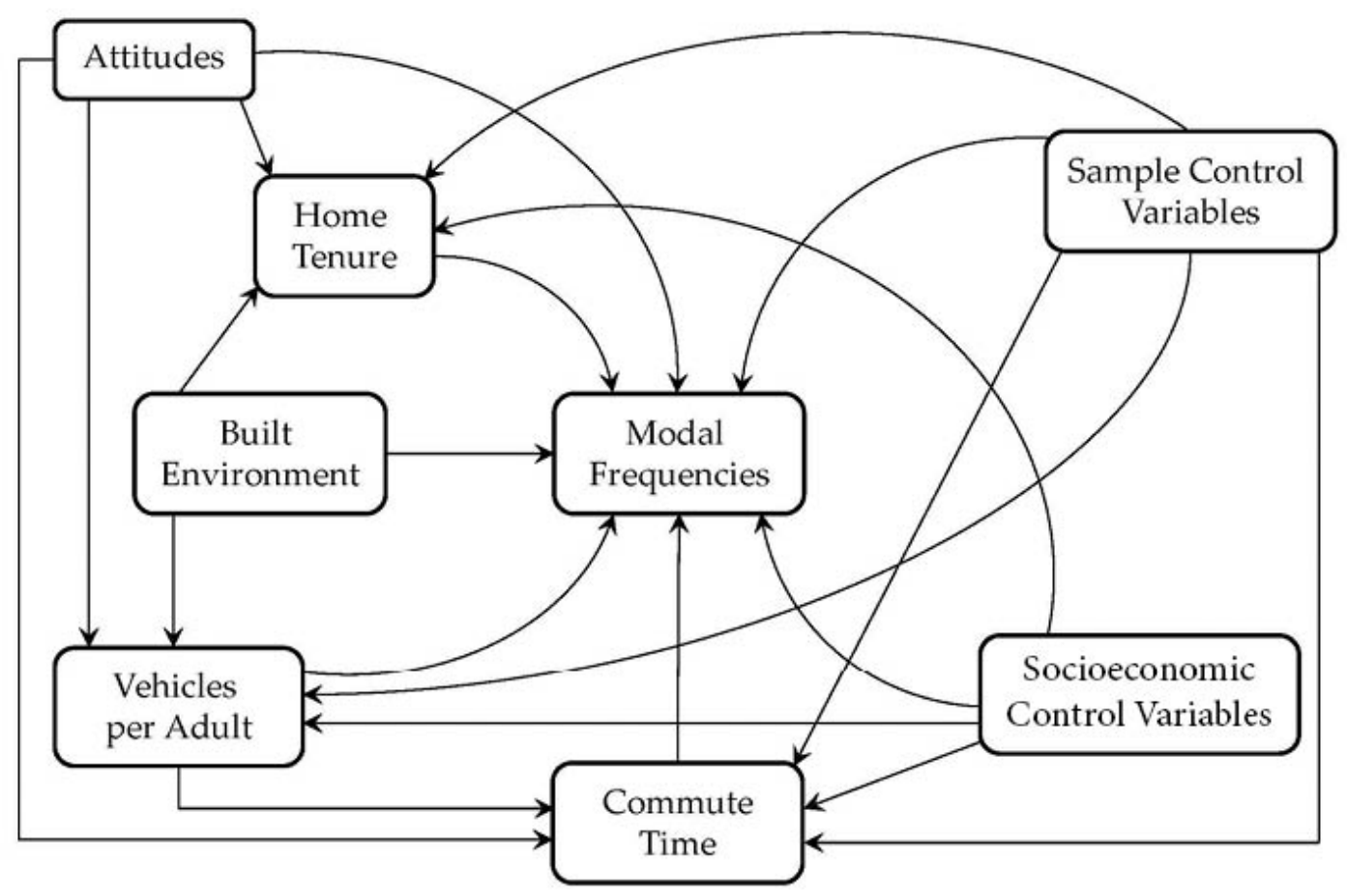

Figure 3: Framework of structural equation model of frequency of modal usage

We include one additional variable, which is the total commute time reported by each respondent. The choice of commute mode is partly determined by how long the commute is. While our modal frequencies are not specifically linked to commuting behavior, we restrict the analysis to those who are commuters. The time devoted to a daily commute can affect the use of other modes. For example, one can imagine a commuter who drives a long distance not walking or using public transit as frequently.

Four additional measures are controlled for using more complex interactions. These are attitudes, home tenure (i.e., how long the respondent has lived in his or her current home), population and employment density and local street density (proxies for the built environment), and vehicle ownership. Attitudes are a major factor affecting the use of each mode, but they also play an indirect effect by how attitudes can influence the choice of where a person lives and his or her vehicle ownership. Our model thus links attitudes to home tenure and vehicle ownership. The built environment is also linked to how long respondents have lived in their home and their vehicle ownership. It is assumed that more walkable built environments presumably lead to longer home ownership and reduced vehicle ownership, thus indirectly affecting the frequency of using each mode of travel. 


\subsection{Measurement of attitudinal variables}

Respondent attitudes toward where they live and their travel choices can influence the choice of residential location and the number of vehicles a household owns. Both are key intervening factors that influence travel choices. We would expect those who have lived in or near a TOD for a shorter period of time to be choosing their residential location partly because of their attitude toward their neighborhood and toward the travel choices available. Thus attitudes help to influence the length of time a household stays in one location, and thus they directly and indirectly affect travel choices. Vehicle ownership also has an influence on the frequency of driving and use of other modes. Attitudes were measured in our survey using the questions shown in Figure 4 and Figure 5.

\begin{tabular}{|c|c|c|c|c|c|}
\hline \multicolumn{6}{|l|}{$\begin{array}{l}\text { People's reasons for selecting a new r } \\
\text { ing a particular house or apartment. } \\
\text { NEIGHBORHOOD. } \\
\text { [Check one for each] }\end{array}$} \\
\hline & $\begin{array}{l}\text { Very } \\
\text { Important }\end{array}$ & \begin{tabular}{|l|} 
Somewhat \\
Important
\end{tabular} & $\begin{array}{l}\text { Neither } \\
\text { Important } \\
\text { or Unim- } \\
\text { portant }\end{array}$ & $\begin{array}{l}\text { Somewhat } \\
\text { Unim- } \\
\text { portant }\end{array}$ & $\begin{array}{l}\text { Not } \\
\text { Important }\end{array}$ \\
\hline a. Close to friends or relatives & $\bullet$ & $\bullet$ & $\bullet$ & $\bullet$ & $\bullet$ \\
\hline b. Close to job & $\bullet$ & $\bullet$ & $\bullet$ & $\bullet$ & $\bullet$ \\
\hline c. Close to train station or bus stop & $\bullet$ & $\bullet$ & $\bullet$ & $\bullet$ & $\bullet$ \\
\hline d. Access to major roads or highways & $\bullet$ & $\bullet$ & $\bullet$ & $\bullet$ & $\bullet$ \\
\hline e. Little or no traffic & $\bullet$ & $\bullet$ & $\bullet$ & $\bullet$ & $\bullet$ \\
\hline f. Easy to park car & $\bullet$ & $\bullet$ & $\bullet$ & $\bullet$ & $\bullet$ \\
\hline g. Good variety of shops and services & $\bullet$ & $\bullet$ & $\bullet$ & $\bullet$ & $\bullet$ \\
\hline h. Low crime rate & $\bullet$ & $\bullet$ & $\bullet$ & $\bullet$ & $\bullet$ \\
\hline i. Good schools & $\bullet$ & $\bullet$ & $\bullet$ & $\bullet$ & $\bullet$ \\
\hline j. Can easily walk in my neighborhood & $\bullet$ & $\bullet$ & $\bullet$ & $\bullet$ & $\bullet$ \\
\hline k. Close to parks or other open space & $\bullet$ & $\bullet$ & $\bullet$ & $\bullet$ & $\bullet$ \\
\hline 1. Other: & $\bullet$ & $\bullet$ & $\bullet$ & $\bullet$ & $\bullet$ \\
\hline
\end{tabular}

Figure 4: Attitudinal questions asked in survey 


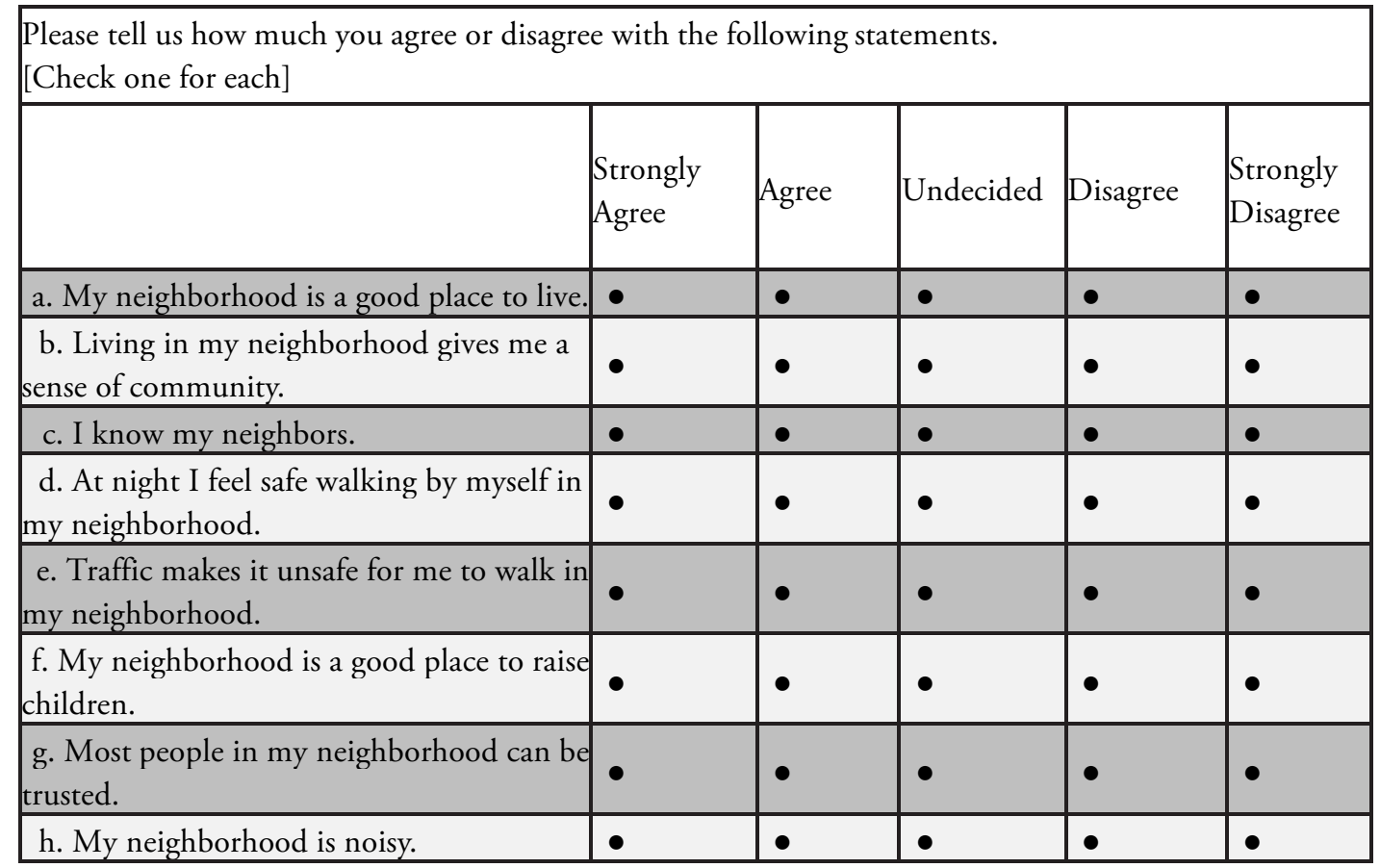

Figure 5: Attitudinal questions asked in survey

In order to use this information in our analysis we conducted a factor analysis to simplify the attitudinal variables. The first step in doing this is to examine the change in the value of the eigenvalue for each factor. Figure 6 shows a screeplot that suggests that five factors are sufficient to account for most of the variation in the 19 factors analyzed. Thus our factor analysis is restricted to five factors. Results are shown in Table 6 after an orthogonal rotation to make interpretation easier. Higher scores (whether positive or negative) have a high loading on that factor and indicate that the factor represents a certain subset of questions; these are highlighted in blue in the table. Loadings that are very low are highlighted in pink and have no effect on that factor.

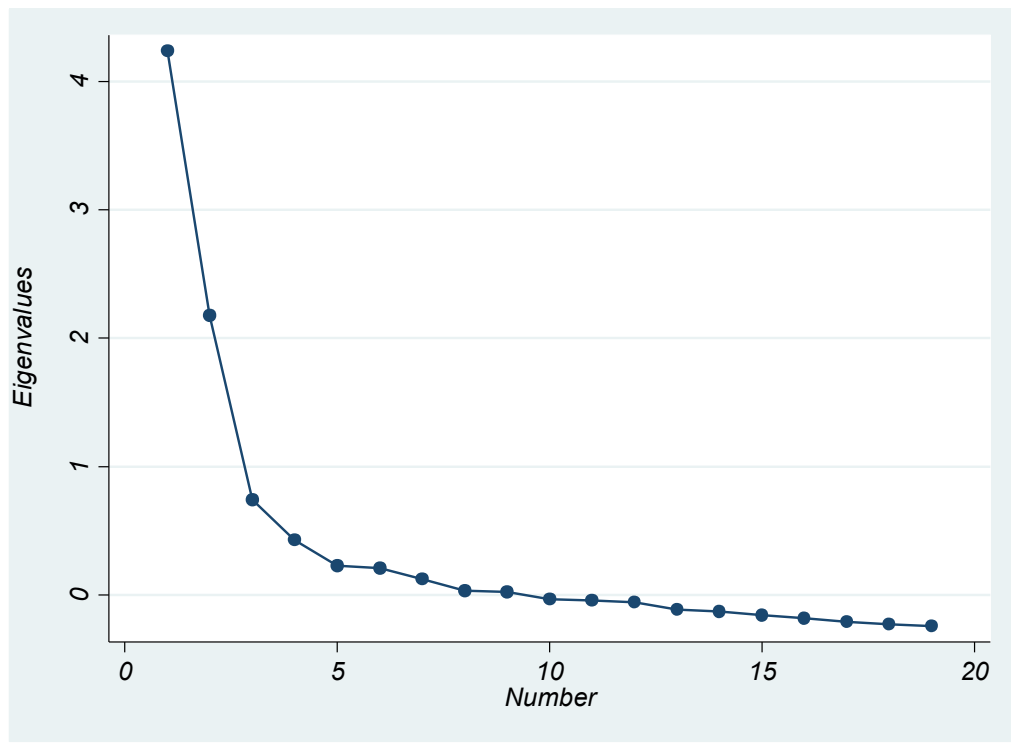

Figure 6: Screeplot of factor eigenvalues 
Table 6: Rotated factor scores

\begin{tabular}{|c|c|c|c|c|c|c|}
\hline $\begin{array}{l}\text { Variable Corresponding to } \\
\text { Questions Listed Above }\end{array}$ & $\begin{array}{l}\text { Factor 1: } \\
\text { Positive } \\
\text { Sense of } \\
\text { Community }\end{array}$ & $\begin{array}{c}\text { Factor 2: } \\
\text { Ability to } \\
\text { Easily } \\
\text { Access } \\
\text { Activities }\end{array}$ & $\begin{array}{l}\text { Factor 3: } \\
\text { Child } \\
\text { Friendly } \\
\text { Neigh- } \\
\text { borhood } \\
\end{array}$ & $\begin{array}{l}\text { Factor 4: } \\
\text { Enjoys } \\
\text { Driving }\end{array}$ & $\begin{array}{l}\text { Factor 5: } \\
\text { Distressed } \\
\text { Community } \\
\end{array}$ & Uniqueness \\
\hline Close to friends or relatives & 0.0673 & 0.104 & 0.2363 & 0.2692 & 0.1868 & 0.8214 \\
\hline Close to job & -0.0542 & 0.3186 & 0.0636 & 0.1632 & 0.0615 & 0.8611 \\
\hline $\begin{array}{l}\text { Close to train station or bus } \\
\text { stop }\end{array}$ & -0.0358 & 0.4415 & -0.1084 & 0.0489 & 0.0155 & 0.7894 \\
\hline $\begin{array}{l}\text { Access to major roads or } \\
\text { highways }\end{array}$ & 0.0402 & 0.2785 & 0.1566 & 0.5023 & 0.0013 & 0.644 \\
\hline Little or no traffic & 0.0542 & 0.2153 & 0.4475 & 0.3227 & -0.0196 & 0.646 \\
\hline Easy to park car & -0.0023 & 0.249 & 0.2349 & 0.5571 & -0.015 & 0.5722 \\
\hline $\begin{array}{l}\text { Good variety of shops and } \\
\text { services }\end{array}$ & 0.1507 & 0.5487 & 0.0859 & 0.2652 & 0.0632 & 0.5945 \\
\hline Low crime rate & 0.1845 & 0.3813 & 0.4133 & 0.1963 & -0.1132 & 0.5984 \\
\hline Good schools & 0.2478 & 0.0445 & 0.5751 & 0.1646 & 0.0955 & 0.5696 \\
\hline $\begin{array}{l}\text { Can easily walk in my neigh- } \\
\text { borhood }\end{array}$ & 0.1738 & 0.5371 & 0.1122 & 0.1598 & -0.0271 & 0.6425 \\
\hline $\begin{array}{l}\text { Close to parks or other open } \\
\text { space }\end{array}$ & 0.1662 & 0.4218 & 0.3199 & 0.213 & 0.0932 & 0.6381 \\
\hline $\begin{array}{l}\text { My neighborhood is a good } \\
\text { place to live }\end{array}$ & 0.7938 & 0.1635 & -0.1001 & 0.0277 & -0.1034 & 0.3217 \\
\hline $\begin{array}{l}\text { Living in my neighborhood } \\
\text { gives me a sense of community }\end{array}$ & 0.7226 & 0.0709 & 0.1256 & 0.1269 & 0.2599 & 0.3735 \\
\hline I know my neighbors & 0.5553 & -0.095 & 0.283 & 0.0957 & 0.3066 & 0.4993 \\
\hline $\begin{array}{l}\text { At night I feel safe walking by } \\
\text { myself in my neighborhood } \\
\text { Traffic makes it unsafe for me }\end{array}$ & 0.7231 & 0.1002 & -0.0781 & -0.0775 & -0.0815 & 0.4483 \\
\hline $\begin{array}{l}\text { to walk in my neighborhood } \\
\text { My neighborhood is a good }\end{array}$ & -0.2244 & 0.1031 & 0.1045 & -0.1352 & 0.3131 & 0.8118 \\
\hline $\begin{array}{l}\text { place to raise children } \\
\text { Most people in my neighbor- }\end{array}$ & 0.8024 & -0.0153 & 0.2177 & -0.0081 & -0.0694 & 0.3036 \\
\hline $\begin{array}{l}\text { hood can be trusted } \\
\text { My neighborhood is noisy }\end{array}$ & $\begin{array}{r}0.7823 \\
-0.4526\end{array}$ & $\begin{array}{l}0.0122 \\
0.1174\end{array}$ & $\begin{array}{r}0.0822 \\
-0.0859\end{array}$ & $\begin{array}{r}0.0326 \\
-0.1035\end{array}$ & $\begin{array}{r}0.0129 \\
0.297\end{array}$ & $\begin{array}{l}0.3799 \\
0.6751\end{array}$ \\
\hline
\end{tabular}

Note: Bold numbers represent high loadings, italic numbers represent low loadings

By evaluating the loadings we can interpret the attitudes represented by each factor. Factor 1 tends to have high loadings on the questions associated with community in the neighborhood. For example, "my neighborhood is a good place to live" and "I know my neighbors." Thus, we interpret factor 1 as representing a positive sense of community.

Factor 2 has high loadings on those questions associated with accessing activities. For example, "close to train or bus stop" and "good variety of shops and services." Therefore, we interpret this as representing a positive attitude associated with having easy access to various activities.

Factor 3 is interpreted as representing a child-friendly neighborhood. High loadings occur on "good schools" and "little or no traffic." Positive attitudes toward these attributes and the others shown in Table 6 suggest the neighborhood is viewed as child friendly. 
The fourth factor has positive loadings on questions that suggest that being able to easily use a car in the neighborhood is perceived as a positive feature. Questions such as "easy to park car" and "access to major roads or highways" have the highest loadings. We define this factor as "enjoys driving."

The final factor has relatively low loadings so is a bit more difficult to interpret. While various questions indicating that respondents feel a sense of community are high, such as "living in my neighborhood gives me a sense of community," others that load high suggest the community has some undesirable features, such as traffic, making it unsafe to walk and the neighborhood being noisy. Thus, we define this factor as a "distressed community." That is, there are positive feelings about the neighborhood as well as recognizable problems.

In all cases these interpretations are subjective and results should be interpreted with that in mind. These are used as independent variables in the multivariate model described next.

\subsection{Structural equation model results}

Results for our structural equation model are shown in Table 7, Table 8, Table 9, Table 11, Table 12, and Table 13. These models are linked together as shown in Figure 3. These tables show the six linked models, each presented separately for simplicity. The number of observations is 779 , reflecting a loss of some respondents due to missing data.

This is a large $\mathrm{N}$ for most SEM analyses, and this creates some potential issues with interpreting the model fit statistics. In particular, it is less likely to find a significant chi-square value as the sample size increases, so it is more likely that the data will show a good model fit when it may not be. Table 14 shows relevant test statistics. The chi-square statistic is not significant, our value has a $\mathrm{p}=0.484$, so issues of significance due to the sample size do not seem to be an issue (Barrett 2007). Other test statistics that are generally reported suggest a good model fit (Iacobucci 2010, Hooper et al. 2008). The Tucker-Lewis Index should be above about 0.95 and the model shows a value of 1.004. The Root Mean Square Area of Approximation (RMSEA) statistic is 0.000 and excellent fit is suggested at values of 0.01 or less.

To investigate whether this loss of respondent data potentially affects the results, we show the mean and standard deviation of each variable for both the full sample and the analysis sample in Table 15 . Those records with more missing values are respondents from the Newark Broad St. and Plainfield subsamples, both relatively lower-income areas. More missing records are from lower-income respondents. On the other hand, we lose fewer respondents from those who live in TODs, and those living between 0.5 and 2 miles have more missing variables. We also have somewhat shorter home tenures in the analysis sample, consistent with the fact that proportionately fewer TOD residents are dropped from the sample. The analysis sample also has slightly younger average household ages, and respondents are more likely to be frequent public transit users. Given the richness of the controls in our data, we do not expect these omissions to affect our analysis; however, we recognize that we mainly lose more of our lowerincome respondents.

Turning to the specific results, Table 7 displays variables that are associated with the length of time the respondent has lived in his or her home. Some 20 percent of the sample has lived in his or her current home for three years or less. The mean is about 13 years, while the median is 8 years. A histogram is shown in Figure 7. Those who live in a TOD development have lived in their current homes for the shortest amount of time, according to the model results. This is not surprising as the TODs in our sample were relatively new. This effect is relative to those living both near the station, but not in a TOD, and those living farther out. The average age of the household is also highly correlated with the length of time living at the current residence. 
Table 7: Structural equation model results-home tenure

\begin{tabular}{lrr}
\hline Dependent variable: Home tenure & \multicolumn{1}{c}{ coef. } & \multicolumn{1}{c}{ z-stat } \\
\hline Factor 1: Sense of community & 0.087 & 2.19 \\
Factor 2: Easy access & 0.015 & 0.38 \\
Factor 3: Child friendly & -0.263 & -5.50 \\
Factor 4: Enjoys driving & 0.065 & 1.32 \\
Factor 5: Distressed community & -0.072 & -1.28 \\
Population density & -0.006 & -0.10 \\
Employment density & -0.014 & -0.69 \\
Local street density (within 0.5-mile radius) & 0.125 & 1.26 \\
Average age of adults in HH & 1.684 & 13.93 \\
Cranford dummy & 0.107 & 0.91 \\
Jersey City dummy & -0.152 & -0.85 \\
Metuchen dummy & 0.084 & 0.69 \\
Morristown dummy & -0.057 & -0.43 \\
New Brunswick dummy & 0.014 & 0.11 \\
Newark dummy & -0.101 & -0.58 \\
Plainfield dummy & 0.127 & 0.86 \\
Lives in a TOD & -0.414 & -3.38 \\
Lives within 0.5 mile of station & -0.036 & -0.52 \\
Constant & -4.538 & -6.73 \\
\hline Note: All continuous
\end{tabular}

Note: All continuous variables are logarithms except factor scores. Station area dummy variables are relative to Rahway. Distance from station dummy variables is relative to those living from 0.50 to 2 miles away. Income dummies are relative to households earning less than $\$ 25,000 /$ year.

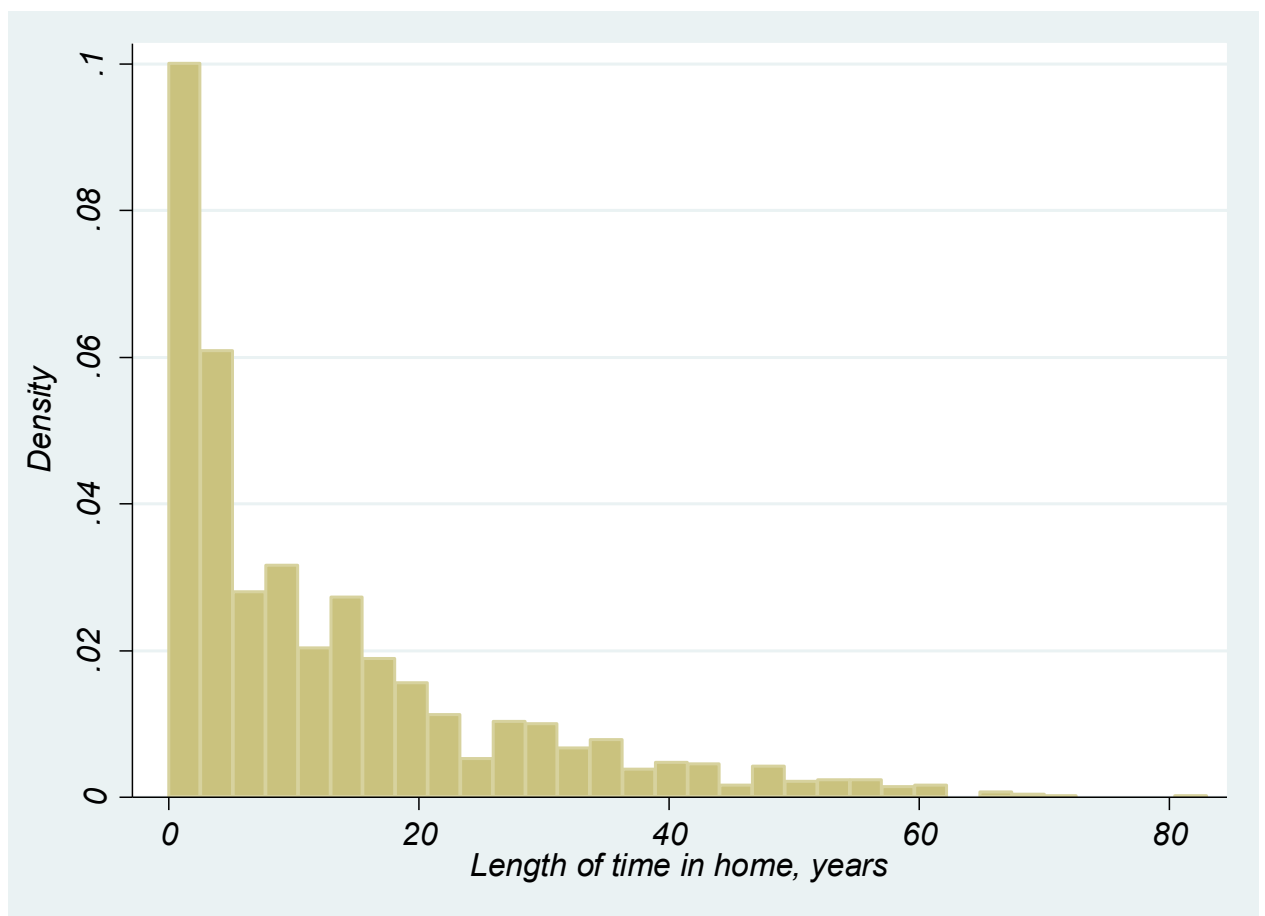

Figure 7: Histogram of home tenure (how long respondent has lived in residence) 
Of more interest, two of the attitudinal factors are statistically significant. Those who have good attitudes about the sense of community in their neighborhood have lived in their current home for a longer period of time. This makes sense as we would expect those who move away to perhaps have moved because of dissatisfaction with their neighborhood. The other statistically significant attitudinal factor is those who have positive attitudes about child-friendly communities have lived there for a shorter period of time. This is somewhat surprising but may reflect transitory patterns of moving to neighborhoods with good schools while one has children in school.

Other variables are not statistically significant at normal confidence levels. We see a positive effect associated with local street density (normally associated with more walkable areas), but it is not statistically significant. Other built environment variables, population and employment density, show no measurable effect.

The commute time model is shown in Table 8. Those living in TODs do not have longer commutes than those living farther out. Those living within 0.5 miles of the station have slightly longer commutes than both other groups, but the statistical significance of this effect is low. Higher income households (above $\$ 150,000$ ) tend to have longer commutes. Of the attitudinal factors, those who feel their neighborhood is child friendly tend to have longer commutes; this may represent decisions to live in communities with child-friendly amenities at the cost of a longer commute trip. Those who feel their community is distressed tend to have shorter commutes, although this is at a low level of statistical significance.

Table 8: Structural equation model results-commute time

\begin{tabular}{lrr}
\hline Dependent variable: Commute time & \multicolumn{1}{c}{ coef. } & \multicolumn{1}{c}{ z-stat } \\
\hline Vehicles per adult & -0.019 & -0.19 \\
Factor 1: Sense of community & -0.032 & -0.75 \\
Factor 2: Easy access & 0.009 & 0.25 \\
Factor 3: Child friendly & 0.106 & 2.04 \\
Factor 4: Enjoys driving & -0.006 & -0.11 \\
Factor 5: Distressed community & -0.099 & -1.58 \\
Cranford dummy & -0.124 & -0.95 \\
Jersey City dummy & 0.106 & 0.55 \\
Metuchen dummy & 0.095 & 0.72 \\
Morristown dummy & -0.395 & -2.66 \\
New Brunswick dummy & -0.198 & -1.56 \\
Newark dummy & 0.014 & 0.07 \\
Plainfield dummy & -0.066 & -0.42 \\
Lives in a TOD & 0.108 & 0.94 \\
Lives within 0.5 miles of station & 0.121 & 1.52 \\
Average age of adults in HH & -0.138 & -1.13 \\
Income 25-75K & 0.019 & 0.16 \\
Income 75-150K & 0.130 & 1.18 \\
Income over 150K & 0.457 & 3.75 \\
Constant & 4.028 & 5.38 \\
\hline Note: All contimous & & 5 Karation
\end{tabular}

Note: All continuous variables are logarithms except factor scores. Station area dummy variables are relative to Rahway. Distance from station dummy variables is relative to those living from 0.50 to 2 miles away. Income dummies are relative to households earning less than $\$ 25,000 /$ year.

Vehicle ownership is often determined by the built environment and the availability of good transit options. Our vehicle ownership sub-model is shown in Table 9. Those who live close to the station tend to have fewer vehicles per household; however, those who live in TODs have as many vehicles as those living farther afield. While we can only speculate, this may be because new TODs are built with ample 
parking availability, while those living within 0.5 miles of the station are more constrained in the amount of space available for parking. Table 10 confirms that those in TODs have ample parking, either surface lots or enclosed structures. Those within 0.5 miles and farther out generally park in their garage or carport, their driveway or on the street. Surprisingly there is no substantive difference in on-street parking locations between these groups. The time devoted to parking is much less for those who do not live in TODs.

Table 9: Structural equation model results—-vehicles per adult in household

\begin{tabular}{lrr}
\hline Dependent variable: Vehicles per adult in household & coef. & z-stat \\
\hline Factor 1: Sense of community & 0.019 & 1.82 \\
Factor 2: Easy access & -0.001 & -0.08 \\
Factor 3: Child friendly & -0.051 & -4.10 \\
Factor 4: Enjoys driving & -0.047 & -3.66 \\
Factor 5: Distressed community & 0.117 & 7.19 \\
Population density & 0.000 & -0.03 \\
Employment density & 0.003 & 0.55 \\
Local street density (within 0.5-mile radius) & 0.005 & 0.15 \\
Cranford dummy & 0.061 & 1.75 \\
Jersey City dummy & -0.171 & -3.94 \\
Metuchen dummy & 0.025 & 0.77 \\
Morristown dummy & 0.056 & 1.40 \\
New Brunswick dummy & -0.011 & -0.31 \\
Newark dummy & -0.123 & -3.17 \\
Plainfield dummy & -0.086 & -2.24 \\
Lives in a TOD & -0.016 & -0.53 \\
Lives within 0.5-mile of station & -0.055 & -2.49 \\
Average age of adults in HH & 0.063 & 1.88 \\
Income 25-75K & 0.015 & 0.50 \\
Income 75-150K & 0.068 & 2.18 \\
Income over 150K & 0.082 & 2.48 \\
Constant & 0.313 & 1.75 \\
\hline Note: H/l continuous
\end{tabular}

Note: All continuous variables are logarithms except factor scores. Station area dummy variables are relative to Rahway. Distance from station dummy variables is relative to those living from 0.50 to 2 miles away. Income dummies are relative to households earning less than $\$ 25,000 /$ year.

Table 10: Parking locations and times by distance from station

\begin{tabular}{lrrr}
\hline Table 10: Parking locations and times by distance from station & & \\
\hline Parking locations & In TOD & Within $0.5 \mathrm{mi}$ & Beyond $0.5 \mathrm{mi}$ \\
\hline Don't own a vehicle & $12.7 \%$ & $9.3 \%$ & $7.6 \%$ \\
Home garage or carport & $10.2 \%$ & $20.6 \%$ & $21.6 \%$ \\
Driveway & $1.5 \%$ & $35.1 \%$ & $42.3 \%$ \\
On-street & $2.0 \%$ & $13.2 \%$ & $14.3 \%$ \\
Surface parking lot & $14.7 \%$ & $12.7 \%$ & $9.3 \%$ \\
Enclosed parking structure & $58.4 \%$ & $7.7 \%$ & $4.0 \%$ \\
Data corrupt & $0.5 \%$ & $1.3 \%$ & $0.9 \%$ \\
\hline Time needed for parking & & & \\
\hline Less than a minute & $51.7 \%$ & $78.3 \%$ & $84.0 \%$ \\
1 to 5 minutes & $41.5 \%$ & $16.3 \%$ & $11.6 \%$ \\
5 to 10 minutes & $6.3 \%$ & $4.5 \%$ & $2.3 \%$ \\
More than 10 minutes & $0.6 \%$ & $0.9 \%$ & $2.1 \%$ \\
\hline
\end{tabular}


Higher-income households also own more cars than lower-income households. The built environment variables have no impact on vehicle ownership. Attitudinal factors are associated with vehicle ownership, the one exception being those who value easy access, which had no statistically significant effect. Sense of community and distressed community factors both had positive associations, while factors for child-friendly community and enjoys driving had negative associations. There is no intuitive pattern associated with these effects, but we include them as controls in the vehicle ownership sub-model.

Our main interest is in how the three variables used to measure travel behavior, namely how the frequency of driving, walking, and public transit use, are associated with both proximity to the station and other controls. These results are shown in Table 11 (for walking frequency), Table 12 (for driving frequency), and Table 13 (for public transit use frequency). Each table shows both direct effects and total effects. The latter include indirect effects associated with the effects estimated by our three sub-models (for home tenure, commute time, and vehicle ownership) that also affect total frequency of using each mode.

Table 11: Structural equation model results-walking frequency

\begin{tabular}{|c|c|c|c|c|}
\hline Dependent variable: Walking frequency & coef. & z-stat & $\begin{array}{c}\text { Total } \\
\text { Effects }\end{array}$ & z-stat \\
\hline Home tenure & -0.092 & -1.93 & -0.092 & -1.93 \\
\hline Commute time & 0.078 & 1.93 & 0.078 & 1.93 \\
\hline Vehicles per adult & -0.643 & -3.99 & -0.643 & -3.99 \\
\hline Factor 1: Sense of community & -0.066 & -1.21 & -0.089 & -1.61 \\
\hline Factor 2: Easy access & -0.105 & -2.05 & -0.105 & -2.04 \\
\hline Factor 3: Child friendly & 0.274 & 4.08 & 0.339 & 5.17 \\
\hline Factor 4: Enjoys driving & 0.319 & 4.31 & 0.342 & 4.66 \\
\hline Factor 5: Distressed community & -0.089 & -1.14 & -0.165 & -2.16 \\
\hline Cranford dummy & 0.196 & 1.22 & 0.138 & 0.85 \\
\hline Jersey City dummy & 0.742 & 3.31 & 0.874 & 3.88 \\
\hline Metuchen dummy & 0.392 & 2.47 & 0.375 & 2.35 \\
\hline Morristown dummy & 0.676 & 3.64 & 0.614 & 3.26 \\
\hline New Brunswick dummy & 0.149 & 0.84 & 0.140 & 0.79 \\
\hline Newark dummy & -0.043 & -0.20 & 0.047 & 0.21 \\
\hline Plainfield dummy & 0.256 & 1.42 & 0.295 & 1.60 \\
\hline Lives in a TOD & 0.415 & 2.70 & 0.472 & 3.12 \\
\hline Lives within 0.5 miles of station & 0.518 & 5.18 & 0.566 & 5.68 \\
\hline Population density & 0.055 & 0.75 & 0.056 & 0.74 \\
\hline Employment density & -0.048 & -1.72 & -0.049 & -1.73 \\
\hline Local street density (within 0.5 -mile radius) & 0.268 & 2.04 & 0.254 & 1.92 \\
\hline Average age of adults in $\mathrm{HH}$ & -0.215 & -1.20 & -0.420 & -2.64 \\
\hline Income $25-75 \mathrm{~K}$ & 0.004 & 0.02 & -0.004 & -0.03 \\
\hline Income $75-150 \mathrm{~K}$ & 0.026 & 0.18 & -0.007 & -0.05 \\
\hline Income over $150 \mathrm{~K}$ & 0.085 & 0.55 & 0.068 & 0.44 \\
\hline Walking frequency - cut 1 & -0.619 & -0.66 & & \\
\hline Walking frequency - cut 2 & -0.184 & -0.20 & & \\
\hline Walking frequency - cut 3 & 0.035 & 0.04 & & \\
\hline Walking frequency - cut 4 & 0.717 & 0.79 & & \\
\hline Walking frequency - cut 5 & -0.042 & -0.05 & & \\
\hline
\end{tabular}

Note: All continuous variables are logarithms except factor scores. Station area dummy variables are relative to Rahway. Distance from station dummy variables is relative to those living from 0.50 to 2 miles away. Income dummies are relative to households earning less than $\$ 25,000 / y e a r$. 
Table 12: Structural equation model results_-driving frequency

\begin{tabular}{|c|c|c|c|c|}
\hline Dependent variable: Driving frequency & coef. & z-stat & $\begin{array}{c}\text { Total } \\
\text { Effects }\end{array}$ & z-stat \\
\hline Home tenure & -0.031 & -0.58 & -0.031 & -0.58 \\
\hline Commute time & -0.349 & -10.29 & -0.349 & -10.29 \\
\hline Vehicles per adult & 1.032 & 6.50 & 1.032 & 6.50 \\
\hline Factor 1: Sense of community & 0.043 & 0.74 & 0.071 & 1.16 \\
\hline Factor 2: Easy access & 0.114 & 1.81 & 0.109 & 1.67 \\
\hline Factor 3: Child friendly & -0.363 & -4.60 & -0.444 & 5.61 \\
\hline Factor 4: Enjoys driving & -0.249 & -3.07 & -0.297 & -3.53 \\
\hline Factor 5: Distressed community & 0.184 & 2.04 & 0.341 & 3.71 \\
\hline Cranford dummy & -0.308 & -1.54 & -0.205 & -0.98 \\
\hline Jersey City dummy & -0.500 & -1.95 & -0.710 & -2.74 \\
\hline Metuchen dummy & -0.176 & -0.87 & -0.186 & -0.89 \\
\hline Morristown dummy & 0.056 & 0.28 & 0.254 & 1.20 \\
\hline New Brunswick dummy & 0.016 & 0.08 & 0.073 & 0.34 \\
\hline Newark dummy & -0.563 & -2.34 & -0.692 & -2.69 \\
\hline Plainfield dummy & -0.202 & -0.84 & -0.272 & -1.08 \\
\hline Lives in a TOD & -0.314 & -1.85 & -0.355 & -2.03 \\
\hline Lives within 0.5 miles of station & -0.155 & -1.30 & -0.252 & -2.07 \\
\hline Population density & -0.131 & -1.53 & -0.131 & -1.50 \\
\hline Employment density & -0.006 & -0.17 & -0.002 & -0.06 \\
\hline Local street density (within 0.5 -mile radius) & -0.045 & -0.31 & -0.044 & -0.30 \\
\hline Average age of adults in $\mathrm{HH}$ & -0.070 & -0.35 & -0.009 & -0.05 \\
\hline Income $25-75 \mathrm{~K}$ & 0.195 & 1.11 & 0.204 & 1.12 \\
\hline Income $75-150 \mathrm{~K}$ & 0.179 & 1.04 & 0.203 & 1.14 \\
\hline Income over $150 \mathrm{~K}$ & 0.153 & 0.85 & 0.078 & 0.43 \\
\hline Driving frequency - cut 1 & 2.364 & 2.04 & & \\
\hline Driving frequency - cut 2 & -3.969 & -3.43 & & \\
\hline Driving frequency - cut 3 & -3.767 & -3.26 & & \\
\hline Driving frequency - cut 4 & -3.502 & -3.03 & & \\
\hline Driving frequency - cut 5 & 0.988 & 0.86 & & \\
\hline
\end{tabular}

Note: All continuous variables are logarithms except factor scores. Station area dummy variables are relative to Rahway. Distance from station dummy variables is relative to those living from 0.50 to 2 miles away. Income dummies are relative to households earning less than \$25,000/year. 
Table 13: Structural equation model results_-public transit use frequency

\begin{tabular}{|c|c|c|c|c|}
\hline Dependent variable: Public transit use frequency & coef. & z-stat & $\begin{array}{c}\text { Total } \\
\text { Effects }\end{array}$ & z-stat \\
\hline Home tenure & -0.076 & -1.57 & -0.076 & -1.57 \\
\hline Commute time & 0.521 & 16.15 & 0.521 & 16.15 \\
\hline Vehicles per adult & -0.912 & -7.65 & -0.912 & -7.65 \\
\hline Factor 1: Sense of community & -0.018 & -0.38 & -0.059 & -1.14 \\
\hline Factor 2: Easy access & -0.062 & -1.37 & -0.058 & -1.16 \\
\hline Factor 3: Child friendly & 0.375 & 5.69 & 0.496 & 7.34 \\
\hline Factor 4: Enjoys driving & 0.233 & 3.46 & 0.268 & 3.68 \\
\hline Factor 5: Distressed community & -0.087 & -1.16 & -0.240 & -2.85 \\
\hline Cranford dummy & 0.148 & 0.99 & 0.020 & 0.12 \\
\hline Jersey City dummy & 0.767 & 3.33 & 0.990 & 4.10 \\
\hline Metuchen dummy & 0.249 & 1.64 & 0.269 & 1.68 \\
\hline Morristown dummy & 0.041 & 0.24 & -0.212 & -1.13 \\
\hline New Brunswick dummy & -0.044 & -0.27 & -0.138 & -0.78 \\
\hline Newark dummy & 0.347 & 1.81 & 0.474 & 2.26 \\
\hline Plainfield dummy & -0.194 & -1.10 & -0.160 & -0.87 \\
\hline Lives in a TOD & 0.427 & 2.94 & 0.530 & 3.40 \\
\hline Lives within 0.5 miles of station & 0.098 & 1.05 & 0.214 & 2.15 \\
\hline Population density & 0.046 & 0.59 & 0.047 & 0.58 \\
\hline Employment density & -0.049 & -1.80 & -0.051 & -1.86 \\
\hline Local street density (within 0.5 -mile radius) & 0.144 & 1.16 & 0.130 & 1.02 \\
\hline Average age of adults in $\mathrm{HH}$ & -0.100 & -0.58 & -0.358 & -2.12 \\
\hline Income $25-75 \mathrm{~K}$ & -0.118 & -0.88 & -0.122 & -0.82 \\
\hline Income $75-150 \mathrm{~K}$ & 0.068 & 0.53 & 0.074 & 0.52 \\
\hline Income over $150 \mathrm{~K}$ & 0.286 & 2.09 & 0.449 & 2.96 \\
\hline Public transit frequency - cut 1 & 4.116 & 3.27 & & \\
\hline Public transit frequency - cut 2 & 2.833 & 2.26 & & \\
\hline Public transit frequency - cut 3 & 1.948 & 1.55 & & \\
\hline Public transit frequency - cut 4 & 2.131 & 1.70 & & \\
\hline Public transit frequency - cut 5 & 2.367 & 1.89 & & \\
\hline
\end{tabular}

Note: All continuous variables are logarithms except factor scores. Station area dummy variables are relative to Rahway. Distance from station dummy variables is relative to those living from 0.50 to 2 miles away. Income dummies are relative to households earning less than \$25,000/year.

Table 14: Test statistics for structural equation model

\begin{tabular}{lc}
\hline Test Statistic & \\
\hline No. of observations & 779 \\
Chi-squared & 7.500 \\
P-value & 0.484 \\
d.f. & 12 \\
Tucker-Lewis Index & 1.004 \\
RMSEA & 0.000 \\
\hline
\end{tabular}


Table 15: Comparison of means for full sample versus analysis sample

\begin{tabular}{|c|c|c|c|c|c|c|c|}
\hline \multirow[b]{2}{*}{ Variable } & \multicolumn{3}{|c|}{ Full sample } & \multicolumn{3}{|c|}{ Analysis sample } & \multirow[b]{2}{*}{ t-stat } \\
\hline & $\begin{array}{c}\text { No. of } \\
\text { observa- } \\
\text { tions }\end{array}$ & Mean & $\begin{array}{l}\text { Std. } \\
\text { Dev }\end{array}$ & $\begin{array}{c}\text { No. of } \\
\text { observa- } \\
\text { tions }\end{array}$ & Mean & Std. Dev & \\
\hline Cranford & 1629 & 0.166 & 0.372 & 779 & 0.168 & 0.374 & -0.15 \\
\hline Jersey City & 1629 & 0.116 & 0.320 & 779 & 0.141 & 0.348 & -1.70 \\
\hline Metuchen & 1629 & 0.200 & 0.400 & 779 & 0.211 & 0.408 & -0.59 \\
\hline Morristown & 1629 & 0.133 & 0.340 & 779 & 0.136 & 0.343 & -0.19 \\
\hline New Brunswick & 1629 & 0.105 & 0.307 & 779 & 0.118 & 0.323 & -0.95 \\
\hline Newark & 1629 & 0.072 & 0.258 & 779 & 0.044 & 0.204 & 2.90 \\
\hline Plainfield & 1629 & 0.079 & 0.269 & 779 & 0.060 & 0.238 & 1.68 \\
\hline Rahway & 1629 & 0.130 & 0.336 & 779 & 0.122 & 0.327 & 0.53 \\
\hline Lives in a TOD & 1629 & 0.125 & 0.330 & 779 & 0.151 & 0.359 & -1.76 \\
\hline Lives within 0.5 miles of station & 1629 & 0.459 & 0.498 & 779 & 0.476 & 0.500 & -0.81 \\
\hline $\begin{array}{l}\text { Lives between } 0.5 \text { and } 2 \text { miles from } \\
\text { station }\end{array}$ & 1629 & 0.417 & 0.493 & 779 & 0.372 & 0.484 & 2.10 \\
\hline Factor 1: Sense of community & 1375 & 0.000 & 0.946 & 779 & -0.021 & 0.916 & 0.50 \\
\hline Factor 2: Easy access & 1375 & 0.000 & 0.881 & 779 & -0.014 & 0.832 & 0.36 \\
\hline Factor 3: Child friendly & 1375 & 0.000 & 0.740 & 779 & 0.094 & 0.755 & -2.80 \\
\hline Factor 4: Enjoys driving & 1375 & 0.000 & 0.622 & 779 & 0.003 & 0.597 & -0.11 \\
\hline Factor 5: Distressed community & 1375 & 0.000 & 0.522 & 779 & -0.003 & 0.523 & 0.12 \\
\hline Log of Home tenure & 1607 & 2.106 & 1.103 & 779 & 1.837 & 1.028 & 5.85 \\
\hline Log of Commute time & 1101 & 3.302 & 0.843 & 779 & 3.291 & 0.864 & 0.29 \\
\hline Log of Vehicles per adult & 1464 & 0.582 & 0.263 & 779 & 0.584 & 0.254 & -0.21 \\
\hline Log of Population density & 1629 & 8.926 & 0.861 & 779 & 8.959 & 0.842 & -0.88 \\
\hline Log of Employment density & 1629 & 7.713 & 1.983 & 779 & 7.902 & 1.987 & -2.19 \\
\hline Log of Local street density (within & & & & & & & \\
\hline 0.5 -mile radius) & 1629 & 2.629 & 0.419 & 779 & 2.617 & 0.398 & 0.68 \\
\hline Walking frequency & 1478 & 4.056 & 1.858 & 779 & 4.022 & 1.883 & 0.41 \\
\hline Driving frequency & 1543 & 5.083 & 1.444 & 779 & 5.035 & 1.573 & 0.72 \\
\hline Public transit use frequency & 1532 & 3.307 & 1.827 & 779 & 3.530 & 1.875 & -2.73 \\
\hline Log of Average age of adults in $\mathrm{HH}$ & 1496 & 3.813 & 0.309 & 779 & 3.706 & 0.268 & 8.57 \\
\hline Income less than $25 \mathrm{~K}$ & 1466 & 0.078 & 0.268 & 779 & 0.031 & 0.173 & 5.02 \\
\hline Income $25-75 \mathrm{~K}$ & 1466 & 0.272 & 0.445 & 779 & 0.248 & 0.432 & 1.26 \\
\hline Income $75-150 \mathrm{~K}$ & 1466 & 0.324 & 0.468 & 779 & 0.388 & 0.488 & -2.99 \\
\hline Income over $150 \mathrm{~K}$ & 1466 & 0.248 & 0.432 & 779 & 0.281 & 0.450 & -1.67 \\
\hline
\end{tabular}




\subsection{Walking frequency}

The frequency of walking is strongly associated with proximity to the train station. Both those living in TODs and those living within 0.5 miles of the station walk more frequently than those living farther out. Surprisingly, those who live in TODs walk a bit less frequently than those living within 0.5 miles of the station. This is despite controlling for other factors, including car ownership, which has a statistically negative association with walking frequency.

Those who have lived in their home for a shorter period of time tend to walk more frequently. This suggests they may have moved to their neighborhood because they valued walking. Those who walk more frequently also seem to have longer total commute times, perhaps because walking is part of their commute trip. Denser local street networks are also associated with increased walking frequency, a result similar to what the literature suggests. Population density, however, had no statistically significant effect, while employment density was negatively associated with walking frequency. Income and age variables had no association with walking frequency.

Results for our attitudinal factors show that those who value easy access to activities tend to walk less frequently. Those who value child-friendly neighborhood attributes walk more frequently, while those with positive attitudes on our enjoy driving factor seem to also be more frequent walkers.

\subsection{Driving frequency}

Variables associated with driving frequency are quite different (Table 12). Those households with higher car ownership tend to drive more frequently. Those with shorter commute times likewise tend to drive more frequently (probably because driving to work tends to reduce commute times). Average age of the household and income do not affect driving frequency.

Proximity to the train station is associated with reductions in driving frequency. Interestingly, this effect is not evident from direct associations between driving frequency, but when indirect effects are included, the data suggest a statistically significant association. Thus, proximity to the station, whether from living in a TOD or living within 0.5 miles of the station is associated with reduced frequency of driving.

The only attitudinal factors associated with increased driving frequency are for valuing easy access and those who feel their neighborhood is distressed. Two other factors have strong negative associations, those who value child-friendly neighborhoods and those who enjoy driving. This latter result is surprising, but one should keep in mind that the definition of these attitudinal factors is subjective.

\subsection{Public transit use frequency}

The frequency with which our survey respondents use public transit is associated with how close they live to the station (Table 13). Those living in a TOD are more frequent public transit users than those living within 0.5 miles of the station; both groups are more frequent users than those living farther from the station. This suggests that those who move into TODs are likely to value the benefit of living near the station.

There are several other key influences on the frequency of using public transit. The more vehicles a household owns, the less frequently the respondent uses public transit. Those with longer commutes are more likely to use public transit (although their commutes may be longer because they use public transit). Respondents in households with income over $\$ 150,000$ per year are also more likely to be frequent users of public transit, though this may be a reflection of our focus on communities served by commuter and light rail. Those in households with a higher average age are less frequent public transit users; this effect is indirect, mitigated by how average age is associated with home tenure and vehicle ownership. Those living in their current resident for longer periods of time also use public transit less frequently, albeit the significance level is low.

Built environment variables do not have a major effect; there is a small negative association with employment density. Perhaps those who live in areas with denser employment can travel to jobs that are closer without using public transit. 


\section{$5 \quad$ Conclusions}

The primary objective of this analysis was to examine the travel behavior of residents living in proximity to train stations and in TODs, as well as to examine the effect of built environment amenities typically associated with more walkable areas. We find strong evidence that those who live near stations and in TODs are more frequent walkers and public transit users while also being less frequent car drivers. Those who live from 0.5 to 2 miles from the station are more frequent car drivers and less frequent walkers and public transit users.

Alternatively, the evidence for how built environment factors influence the frequency of using these three modes is more limited. In most models there is no statistically significant effect associated with population density. We find mild negative effects associated with employment density and both walking and public transit use frequency. The one built environment measure that seems to influence walking is local street network density, which has a positive association with more frequent walking.

Several control variables are important to note. First, vehicle ownership affects the frequency of using all the modes. Increased vehicle ownership leads to more frequent driving and less frequent walking and public transit use. The length of time a respondent has lived in his or her current home tends to reduce the frequency of walking but does not affect the frequency of using other modes. This suggests that people who have moved more recently may have chosen their home location partly because of the walkability of the area around the station. Older households also tend to walk and use public transit less frequently. Those with higher incomes have an increased frequency of using public transit, but there is no difference in the frequency of their use of other modes.

The attitudinal control variables are in some cases difficult to interpret. These are composite variables calculated via factor analysis, and results should be interpreted in light of the subjective interpretation of the factor analysis. The factors tend to show opposite associations between driving frequency and with walking and public transit use frequency. This does suggest some underlying neighborhood preferences and attitudes toward each mode that these variables are controlling for. Controlling for these underlying attitudes is really the key purpose of including these variables in the model to minimize issues associated with self-selection bias.

To conclude, this analysis suggests that those living in TODs and transit-station areas are more likely to both use public transit and to walk more frequently compared to those living farther afield. The attitudinal controls in our model were intended to minimize self-selection bias as was the control for how long people had lived in their current residence; those who have moved more recently tend to walk more. The simultaneous control for the frequency of using three modes of travel is unique to our analysis. The results generally meet our expectations of the impact of TODs on travel behavior.

\section{Acknowledgments}

This material is based on work supported by both the New Jersey Department of Transportation and the U.S. Department of Transportation's University Transportation Centers Program under grant number DTRT12-G-UTC21. The contents of this report reflect the views of the authors, who are responsible for the facts and the accuracy of the information presented herein. This paper is disseminated under the sponsorship of the U.S. Department of Transportation's University Transportation Centers Program in the interest of information exchange. The U.S. government assumes no liability for the contents or use thereof. We thank the staffs at NJ Transit and NJ DOT for their guidance on this project. 


\section{References}

Arrington, G. B., R. Cervero, National Research Council, Transportation Research Board, Federal Transit Administration, Transit Development Corporation, and Transit Cooperative Research Program. 2008. Effects of TOD on Housing, Parking, and Travel. Washington, DC: Transportation Research Board.

Barrett, P. 2007. Structural equation modeling: Adjudging model fit. Personality and Individual Differences 42(5): 815-824.

Bartholomew, K., and R. Ewing. 2010. Hedonic price effects of pedestrian and transit-oriented development, working paper. Salt Lake City, UT: University of Utah.

Bartholomew, K., and R. Ewing. 2011. Hedonic price effects of pedestrian- and transit-oriented development. Journal of Planning Literature 26(1): 18-34.

Boarnet, M. G., D. Houston, G. Ferguson, and S. Spears. 2010. Land use and Vehicle Miles of Travel in the Climate Change Debate: Getting Smarter than Your Average Bear.

Cambridge Systematics Inc. 2006. The Role of State DOTs in Support of Transit-Oriented Development (TOD).

Cao, X., P. L. Mokhtarian, and S. L. Handy. 2009a. The relationship between the built environment and non-work travel: A case study of Northern California. Transportation Research Part A 43(5): 548559.

Cao, X., P. L. Mokhtarian, and S. L. Handy. 2009b. Examining the impacts of residential self-selection on travel behavior: A focus on empirical findings. Transport Reviews 29(3): 359-395.

Cervero, R. and G. B. Arrington. 2008. Vehicle trip reduction impacts of transit-oriented housing. Journal of Public Transportation 11(3): 1-18.

Cervero, R. 2004. Transit-Oriented Development in the United States: Experiences, Challenges, and Prospects, TCRP Report 102. Washington, DC: Transportation Research Board.

Chatman, D. G. 2009. Residential choice, the built environment, and non-work travel: Evidence using new data and methods. Environment and Planning A 41(5): 1072-1089.

Chatman, D. and S. E. DiPetrillo. 2010. Eliminating Barriers to Transit-Oriented Development. Trenton, NJ: New Jersey Department of Transportation.

Dillman, D. A. 2000. Mail and Internet Surveys: The Tailored Design Method. Vol. 2. New York: Wiley.

Ewing, R. and R. Cervero. 2010. Travel and the built environment: A meta-analysis. Journal of the American Planning Association 76(3): 265-294.

Hooper, D., J. Coughlan, and M. Mullen. 2008. Structural equation modelling: Guidelines for determining model fit. The Electronic Journal of Business Research Methods 6(1): 53-60.

Iacobucci, D. 2009. Everything you always wanted to know about SEM (structural equations modeling) but were afraid to ask. Journal of Consumer Psychology 19(4): 673-680.

Iacobucci, D. 2010. Structural equations modeling: Fit indices, sample size, and advanced topics. Journal of Consumer Psychology 20(1): 90-98.

Rosseel, Y. 2012. Lavaan: An R package for structural equation modeling. Journal of Statistical Software 48(2): 1-36. 